\title{
THE IMAGE OF PRESIDENT CANDIDATE JOKO WIDODO IN CAMPAIGN ADVERTISEMENT IN THE PRESIDENT ELECTION 2019
}

\author{
Muhammad F. Ridwan', Aquarini Priyatna ${ }^{2}$, dan Lina Meilinawati ${ }^{3}$ \\ 1 Universitas Padjadjaran, Bandung, Indonesia \\ ${ }^{2}$ Universitas Padjadjaran, Bandung, Indonesia \\ ${ }^{3}$ Universitas Padjadjaran, Bandung, Indonesia \\ Email: fauzibenridwan@gmail.com
}

\begin{abstract}
This research focuses on Joko Widodo's and KH Maruf Amin's campaign in the 2019 presidential election. The purpose of this study is to find out how Joko Widodo imaged himself in his political campaign adverts, and how ideas and meanings are articulated in political advertisements. The study uses a descriptive qualitative research with Roland Barthes's Semiotic analysis approach. The results showed that Joko Widodo was represented as a simple leader, populist, and close to a low society, and could bring Indonesia forward and prosper through some of his programs are Kartu Prakerja or the Pre-Employment Card, Kartu Indonesia Pintar Kuliah or Indonesia Smart College Card, and Kartu Sembako Murah or Cheap Basic Food Cards.
\end{abstract}

Keywords: Image, political advertising, Semiotics, and President Election 2019

\begin{abstract}
ABSTRAK
Penelitian ini fokus pada iklan kampanye Joko Widodo dan KH Maruf Amin pada pemilihan presiden 2019. Tujuan penelitian ini untuk mengetahui bagaimana Jokowi mencitrakan diri pada iklan kampanye politiknya, dan bagaimana gagasan dan makna diartikulasikan dalam iklan politik tersebut. Penelitian menggunakan jenis penelitian deskriptif kualitatif dengan pendekatan analisis Semiotika milik Roland Barthes. Hasil penelitian menunjukkan bahwa Jokowi direpresentasikan sebagai pemimpin sederhana, merakyat, dan dekat masyarakat kecil, serta bisa membawa Indonesia maju dan sejahtera melalui program Kartu Prakerja, Kartu Indonesia Pintar Kuliah, dan Kartu Sembako Murah.
\end{abstract}

Kata kunci: Citra, iklan kampanye, Semiotika, dan Pemilihan Presiden 2019

\section{PENDAHULUAN}

Era reformasi tahun 1998 silam dan mulai berkembangnya teknologi informasi secara masif di Indonesia membuka keran saluran informasi yang mudah diperoleh dan dikonsumsi oleh khalayak masyarakat secara terbuka lebar. Salah satu penopang yang membuat informasi mudah diakses masyarakat adalah bermunculan media mainstream, baik media cetak, media daring, dan media elektronik. Hal itu diperkuat dengan lahirnya Undang-Undang (UU) Kebebasan Pers Nomor 40 tahun 1999, dalam poin b pertimbangan UU, kehidupan bermasyarakat, berbangsa dan bernegara yang demokratis, kemerdekaan menyatakan pikiran dan pendapat sesuai dengan hati nurani dan hak memperoleh informasi merupakan hak asasi manusia yang sangat hakiki, diperlukan untuk menegakan keadilan dan kebenaran, memajukan kesejahteraan umum dan 


\section{CAPTURE}

mencerdaskan bangsa. Tidak hanya itu, semua orang dan kalangan bisa mendirikan perusahaan pers.

Yosep Adi Prasetyo menyatakan berdasarkan data dari Jurnal Dewan Pers (2018), di Indonesia terdapat total 47.000 media. Sejumlah 43.300 merupakan media daring dan sekitar 2000-3000 merupakan media cetak. Sisanya adalah radio dan stasiun televisi yang memiliki siaran berita (Y. A. Prasetyo, 2018). Kemudahan mendirikan perusahaan pers turut berkontribusi terhadap munculnya perusahaan abal-abal yang mendirikan media massa untuk kepentingan bisnis. Dewan Pers baru memverifikasi sekitar 2.400 perusahaan pers yang tergolong sebagai media profesional (Y. A. Prasetyo, 2018).

Di luar media mainstream, bermunculan flatform baru yaitu media sosial (medsos) seperti facebook yang lahir pada tahun 2004, twitter pada tahun 2006, instagram pada tahun 2010, dan media berbasis chatting seperti di antaranya line yang ada pada tahun 2011 (Wikipedia, 2019). Meski bukan dikategorikan sebagai perusahaan pers dan karyanya bukan karya jurnalistik, namun penguna media sosial terus meningkat, misalnya we are social. Menurut riset Simon Kemp, situs we are social merupakan perusahaan media asal Inggris bekerjasama dengan Hootsuite, situs layanan manajemen konten (Kemp, 2019).
Simon Kemp memetakan bahwa dari jumlah populasi masyarakat Indonesia yang mencapai 268,2 juta jiwa, sekitar 355,5 juta orang pengguna telepon genggam (ponsel pintar dan tablet), dan 150 juta orang atau 56 persen dari penduduk Indonesia merupakan pengguna internet, termasuk mereka yang aktif menggunakan media sosial. Apabila dibandingkan dengan tahun 2018, pengguna internet tahun 2019 naik sekitar 13 persen dan yang aktif di media sosial naik 15 persen, sedangkan pengguna media sosial di telepon genggam (mobile social media users) naik 8,3 persen. Selain itu, penggunaan telepon genggam paling tinggi mencapai 91 persen, laptop/PC hanya 22 persen, dan penggunaan televisi masih mendominasi yaitu sekitar 95 persen (Kemp, 2019).

Rata-rata orang Indonesia menghabiskan waktu menggunakan internet mencapai 8 jam 36 menit per hari. Selanjutnya, media sosial dengan 3 jam 26 menit, dan televisi dengan lama menonton 2 jam 52 menit. Terakhir, streaming musik dengan lama waktu 1 jam 22 menit.

Media sosial youtube, whatsapp, facebook adalah tiga besar platform yang banyak digunakan oleh masyarakat Indonesia, disusul oleh instagram, line dan twitter. Pengguna media sosial didominasi oleh kalangan masyarakat berusia 18 hingga 34 tahun.

Determinasi media mainstream dan media sosial di masyarakat menjadi peluang 
bagi berbagai kalangan untuk mempromosikan sesuatu baik yang berbentuk produk (bisnis) atau diri sendiri (individu) dalam konteks politik. Promosi biasa dilakukan di media mainstream seperti media cetak, media elektronik (televisi dan radio) dan media sosial dalam bentuk iklan (Kemp, 2019). Promosi dalam konteks politik, dapat dilihat pada pemilihan presiden Indonesia tahun 2014 dan 2019, salah satunya calon presiden Joko Widodo Joko Widodo (Jokowi), politisi asal Solo, Jawa Tengah memiliki karir politik cemerlang. Presiden Republik Indonesia periode 2014-2019 ini mencalonkan kembali sebagai calon presiden nomor urut 01 periode 2019-2024 didampingi oleh calon wakil presiden $\mathrm{KH}$ Maruf Amin dan berhasil menang. Pesaingnya adalah nomor urut 02 Prabowo Subianto dan Sandiaga Salahudin Uno.

Sebelum menjabat presiden Republik Indonesia selama dua periode, Jokowi pernah menjabat sebagai Wali Kota Solo dua periode sejak tahun 2005 hingga tahun 2012. Tahun 2012 ia mencalonkan diri sebagai Gubernur DKI Jakarta dan berhasil menang mengalahkan petahana calon Gubernur DKI Jakarta, Fauzi Bowo.

Salah satu faktor yang dapat diargumentasikan dan dimungkinkan bahwa Jokowi memenangkan kontestasi politik, karena kuatnya citra dan branding yang melekat pada dirinya. Hal itu senada yang diungkapkan oleh Rusmulyadi (2018) bahwa salah satu keberhasilan Jokowi memenangkan pemilihan presiden 2014 adalah karena citra dan branding yang kuat (Rusmulyadi \& Hafiar, 2018).

Dhani (2017) pada media daring Tirto.id mengatakan bahwa Jokowi telah mengubah model kepemimpinan yang sebelumnya terkesan kaku, birokratis, dan serba protokoler menjadi lebih cair, humanis, dan dekat dengan masyarakat (Dhani, 2017). Model kepemimpinannya dikemukakan Y. A. Prasetyo pada media daring Antara yaitu seusai melakukan pertemuan dengan Prabowo Subianto dilanjutkan jumpa pers di istana negara, wartawan meminta Jokowi dan Prabowo bersalaman dan berswafoto sebelum keluar ruangan. Tiba-tiba, Jokowi menghampiri wartawan dan meminjam telepon genggam milik salah seorang wartawan. la melakukan swafoto bersama Prabowo dengan latar belakang belasan wartawan yang aktif meliput di istana negara. Jokowi pun menampilkan diri sebagai orang yang sederhana, dekat, dan tidak kaku saat berdialog dengan masyarakat (B. Prasetyo, 2019).

Di kalangan milenial atau generasi yang lahir dari tahun 1980 hingga tahun 2000, Krismantari menulis pada media daring The Conversation, sosok Jokowi menampilkan diri sebagai sosok yang 'gaul' melalui atribut penggunaan motor besar, sneakers, dan jaket jeans. Cara itu dilakukannya untuk menggaet pemilih 


\section{CAPTURE}

pemula pada pemilihan presiden 2019 (Krismantari, 2018).

Pada pemilihan presiden 2019, kampanye Jokowi dalam iklan kampanye politik di televisi dan channel Komisi Pemilihan Umum (KPU) Republik Indonesia di media sosial Youtube berfokus pada tiga hal. Pertama, tiga kartu sakti Jokowi yang terdiri dari Kartu Prakerja, Kartu Sembako, dan Kartu Indonesia Pintar (KIP) Kuliah. Kedua, pencitraan sebagai sosok seorang bapak. Pencitraan ini muncul melalui penggambaran aktivitas Jokowi dan $\mathrm{KH}$ Maruf Amin yang melakukan blusukan ke masyarakat di seluruh Indonesia. Ketiga, ajakan langsung kepada masyarakat untuk memilih Jokowi dan KH Maruf Amin dengan mempengaruhi dan mengarahkan pemilih untuk mencoblos. Ketiga hal tersebut dapat diasumsikan sebagai citra politik Jokowi dan K.H. Maruf Amin.

Penggambaran iklan politik sebagai bentuk pencitraan, Firmanzah berpendapat yang dikutip Rusmulyadi dan Hafiar bahwa citra politik tidak selalu sama dengan kondisi realitas yang ada. Citra politik dibangun untuk menunjukkan kesan yang baik kepada publik tentang seseorang dan mengandung imajinasi tentang sosok ideal yang ingin ditampilkan. Kondisi sehariharinya, bisa terjadi sesorang sangat jauh dari kesan baik yang dimunculkan atau dari sosok ideal dalam iklan politik tersebut (Rusmulyadi \& Hafiar, 2018).

Stuart Hall (dalam Storey, 2008) menyatakan bahwa citra atau gambaran tentang seseorang yang ditampilkan dalam sebuah med ia massa, dalam hal ini iklan politik, dikontruksi sesuai citra yang diinginkan oleh aktor politik tersebut. Berbagai atribut disematkan kepada seseorang agar citra terbangun dan masyarakat yang melihatnya bisa memiliki kesan yang baik. Citra yang dikontruksi oleh seseorang dalam iklan politik dilakukan dengan mengerahkan sumber daya yang ada dan memanfaatkan infrastruktur yang dimiliki. Pembentukan citra dilakukan untuk mengarahkan pikiran masyarakat untuk memilih aktor politik tersebut.

Contoh relevan adalah seperti yang ditulis Liputan6.com yaitu calon anggota DPD Provinsi NTB pada pemilihan anggota DPD 2019, Evi Apita Maya yang digugat Muhammad Farouk (calon anggota DPD Provinsi NTB), karena foto yang digunakan untuk mendaftar sebagai calon legislatif dinilai terlalu cantik. Keterangan Evi dalam sidang Mahkamah Konstitusi (MK) bahwa Evi menganggap editing pada foto pencalonannya hal yang wajar. Gugatan sengketa pemilu yang diajukan akhirnya ditolak MK (Liputan6com, 2019).

Cara Jokowi dalam mencitrakan diri pada iklan kampanye politik di pemilihan presiden 2019 patut dikaji secara mendalam untuk memetakan pola pencitraan yang ditampilkan. Bagaimanapun juga, citra politik mempunyai kapasitas untuk mengarahkan pemilih untuk mencoblos 
Jokowi.

Daniel Chandler (dalam Setianto et al., 2016) mengatakan iklan politik bersifat epidemik. Iklan politik memenetrasi dan menggiring pikiran masyarakat untuk menentukan pilihan kepada salah satu kandidat. Peneliti dari Pusat Kajian Politik (Puskapol) UI menjelaskan bahwa intensitas iklan politik di media massa turut berpengaruh terhadap pilihan pemilih (Budi, 2013).

Di dalam kajian budaya, citra atau representasi memiliki porsi yang besar untuk dibahas, yakni bagaimana dunia dikonstruksi dan direpresentasikan melalui berbagai medium kepada masyarakat (Barker, 2008). Iklan politik memiliki tanda verbal atau ekspresi (tuturan dan lainnya) dan tanda nonverbal (gambar dan lainnya). Tanda-tanda atau penanda yang muncul tersebut merujuk kepada sebuah konsep atau gagasan (petanda). Barthes (dalam Hoed, 2011) mengungkapkan pemakai tanda tidak hanya memaknai (tanda) sebagai denotasi atau sistem pertama. Namun, mengembangkan menjadi sistem yang kedua.

Penelitian iklan kampanye politik Jokowi ini dilakukan dengan pendekatan Semiotika. Rumusan masalah penelitian iklan politik ini sebagai berikut: (1) bagaimana Jokowi mencitrakan diri dalam tiga iklan kampanye politik pada pemilihan presiden 2019, dan (2) bagaimana gagasan Jokowi yang diartikulasikan dalam ketiga iklan kampanye politik pada pemilihan presiden 2019.

\section{TINJAUAN PUSTAKA}

2.1. Citra dalam Iklan Politik

Adorno \& Horkheimer (dalam Narendra et al., 2019) melihat industri budaya membuat media-media budaya menjadi sebuah media yang menentukan arah serta bentuk kehidupan manusia pada saat itu ataupun masa mendatang. Media budaya tersebut termasuk iklan komersil.

Iklan komersil pada media elektronik yaitu televisi ataupun media cetak dan media daring dianggap menjadi salah satu strategi efektif dalam memasarkan sebuah produk. Sumbo Tinarbuko mengatakan bahwa peran dan fungsi iklan dalam perkembangan bisnis modern sangat penting sebab ia berusaha menawarkan kelebihan sebuah produk dan memengaruhi calon konsumen untuk membeli barang atau jasa (Tinarbuko, 2009).

Bentuk dan konten iklan yang ditawarkan kepada masyarakat, Yasraf Amir Piliang mengatakan bahwa memuat citra atau gambaran (representasi) yang berisi konsep, gagasan, tema atau ide-ide tentang sebuah produk. Namun, citra tersebut tidak berkaitan dengan subtansi produk yang ditawarkan. Ilusi dan manipulasi adalah citra yang digunakan untuk mendominasi selera masyarakat agar mereka tergerak membeli sebuah produk tersebut. Bentuknya di antaranya adalah penggunaan representasi tubuh, organ tubuh perempuan agar hasrat 


\section{CAPTURE}

membeli terangsang (Piliang, 2019).

Argumentasi Ardianto (dalam

Rusmulyadi \& Hafiar, 2018) tentang konsep

citra yaitu perasaan atau gambaran diri publik terhadap perusahaan, organisasi atau lembaga, kesan yang dengan sengaja diciptakan dari suatu objek, orang atau organisasi. Definisi ini mengisyaratkan citra adalah segala sesuatu yang sengaja ditampilkan oleh organisasi atau lembaga untuk mendapatkan kesan positif dari publik. Oleh karenanya, citra merupakan salah satu modal penting bagi organisasi dalam membangun opini publik. Opini publik yang terbentuk akan menggiring dan mendorong publik untuk bersikap partisipatif dan loyal terhadap langkah dan kebijakan organisasi.

Praktik manipulasi melalui citra atau penggambaran terjadi dalam iklan politik kampanye. Aktor politik membangun citra dengan membuat iklan politik. Kaid (dalam Rully, 2018) mendiskusikan bahwa iklan politik merupakan alat utama dalam pemasaran politik bahkan mendominasi komunikasi antara aktor politik dengan masyarakat luas.

Aktor politik menawarkan produk dan jasa melalui iklan politik kepada masyarakat untuk meraih dukungan. Produk yang dipasarkan adalah mengenai citra individu dan program-program politik (Subinarto, 2019). Masli-Setiono (dalam Setianto et al., 2016) berargumentasi bahwa aktor politik melakukan sosialisasi kepada masyarakat dengan mencitrakan diri secara positif dan baik melalui iklan politik.

Citra seorang aktor politik yang positif agar bisa tertanam pada pikiran masyarakat harus dilakukan secara simultan serta berkelanjutan (Rusmulyadi \& Hafiar, 2018). Lakoff dan Mark Johnson dalam (Danesi, 2011) mengatakan bahwa citra sebagian besar didefinisikan sebagai kerangka mental tak sadar dari bentuk, tindakan, dimensi dan seterusnya yang terus berulang dan berasal dari persepsi dan perasaan. Skema citra sebagian besar bersifat tak sadar namun dapat dibangkitkan dengan mudah dan menuntun terbentuknya konsep umum.

Arifin (dalam Rusmulyadi \& Hafiar, 2018) mengatakan bahwa dalam politik, citra merupakan gambaran publik tentang dunia politik, sedangkan pada dirinya, politik adalah wilayah kontestasi, kompetisi dan konflik yang lahir karena perebutan kekuasaan. Maka, citra politik dapat bermakna gambaran dan persepsi publik tentang otoritas, kekuasaan, kewenangan, konsensus dan konflik yang memiliki makna tersendiri. Menurut Abas Fauzi, nilai utama iklan adalah simbolik citra yang baik yang dapat ditampilkan (Fauzi, 2018).

Stuart Hall (dalam Storey, 2008) menjelaskan bahwa citra seseorang yang ditampilkan di media massa dalam hal ini iklan politik dikontruksi berdasarkan yang diinginkan. Berbagai atribut disematkan 
kepada seseorang agar citra terbangun dan masyarakat yang melihatnya bisa memiliki kesan yang baik.

Dua teknik utama yang membuat iklan menjadi lebih kuat diingat oleh masyarakat yaitu pemosisian dan penciptaan citra. Pemosisian ialah penempatan atau penargetan sebuah produk bagi orang-orang yang tepat. Penciptaan sebuah citra untuk sebuah produk, termasuk membentuk sebuah 'kepribadian' bagi produk itu. Citra adalah tanda yang terbuat dari paduan nama produk, pengemasan, logo, harga dan presentasi keseluruhan yang menciptakan sifat yang dikenal dari produk itu (Danesi, 2011).

Pendapat Stuart Hall (dalam Storey, 2008) bahwa kontruksi citra dilakukan dengan melibatkan sumberdaya atau infrastruktur yang memadai yaitu orang-orang yang kompeten di bidangnya untuk menciptakan citra yang positif dan baik. Kedua, cara pandang dalam mengkontruksi citra pada iklan politik serta memahami karakteristik penerima pembaca pesan akan berdampak pada hasil yang diproduksi dan dapat diterima oleh masyarakat. Masyarakat menerima pesan tentang citra iklan seorang aktor politik bisa berbeda dengan yang diharapkan oleh pembuat atau yang mengontruksi citra seseorang tersebut. Perbedaan tersebut dilatarbelakangi oleh pengetahuan, pengalaman dan pemikiran masyarakat tersebut.

Proses pencitraan produk agar melekat di masyarakat, Danesi berpendapat bahwa hal itu dapat dilakukan dengan teknik mitologisasi yaitu strategi menanamkan makna mitis pada nama merek, logo, rancangan produk, iklan, dan pariwara. Danesi mencontohkan penamaan merek pada produk lebih dari sekedar identifikasi sebuah produk namun dikontruksi untuk mencitrakan sistem signifikansi bagi produk. Pada level informasi praktis, penamaan produk memiliki fungsi denotatif tetapi pada level konotatif nama produk menghasilkan citra yang melampaui fungsi identifikasi yang sederhana (Danesi, 2011).

\subsection{Pendekatan Semiotika}

Citra dan gagasan dalam sebuah iklan politik muncul dalam bentuk tandatanda verbal maupun nonverbal. Penelitian terhadap tanda-tanda dalam iklan politik bisa dikaji dengan mengunakan teori analisis Semiotika Roland Barthes. Pemikir asal Perancis ini mengembangkan konsep petanda-penanda milik ahli linguistik Ferdinand De Saussure. Benny Hoedoro Hoed berpendapat bahwa pada kehidupan sosial budaya, petanda adalah ekspresi (E) dan petanda adalah isi (Contenu, bahasa Perancis). Menurutnya, tanda adalah relasi (R) antara $E$ dan $C$ atau model E-R-C (Hoed, 2011).

Barthes (dalam Hoed, 2011) mengatakan bahwa pemakai tanda tidak hanya memaknai (tanda) sebagai denotasi 


\section{CAPTURE}

atau sistem pertama, namun

Data yang terkumpul dianalisis mengembangkan menjadi sistem yang kedua. Salah satunya pengembangan pada segi $E$ di mana pemakai tanda memberikan bentuk berbeda untuk makna yang sama nama. Proses tersebut dinamakan metabahasa. Sementara, jika proses pengembangan mengarah kepada $\mathrm{C}$ maka disebut konotasi. Konotasi merupakan makna baru yang diberikan pemakai tanda sesuai keinginan, latar belakang pengetahuan. Konotasi merupakan segi ideologi tanda. Makna khusus adalah konotasi.

\section{METODE}

Penelitian ini mengunakan jenis penelitian kualitatif dengan pendekatan Semiotika Roland Barthes. Benny Hoedoro Hoed mengatakan penelitian semiotik cenderung menggunakan paradigma kualitatif. Metode yang menggolongkan data atas data auditif, tekstual dan audiovisual. Iklan politik yang akan dianalisis memakai studi literature (Hoed, 2011).

Iklan yang menjadi objek penelitian adalah tiga jenis iklan politik pasangan calon presiden dan wakil presiden 2019-2024 nomor urut 01 Joko Widodo dan KH Maruf Amin yang ditayangkan di media televisi pada 24 Maret hingga 13 April 2019 dan resmi terdaftar di KPU RI. Pemilihan ketiga iklan kampanye tersebut dengan teknik Purposive Sampling. Data diambil dari media sosial, Youtube yang diakses pada Oktober 2019. menggunakan analisis Semiotika Roland Barthes. Pada tahap pertama, analisis diarahkan untuk melihat tanda-tanda verbal dan nonverbal (denotatif atau literal) dalam ketiga iklan kampanye politik yang memiliki tema berbeda-beda. Analisis dilanjutkan dengan melihat tanda-tanda konotatif atau makna baru (gagasan) pada iklan kampanye Jokowi yang diberikan pemakai tanda sesuai keinginan dan latar belakang pengetahuan, dan tahap berikutnya memberikan kesimpulan dari hasil analisis yang dilakukan.

\section{PEMBAHASAN}

\subsection{Iklan Tiga Kartu Sakti Jokowi}

Iklan politik pasangan calon presiden dan wakil presiden, Joko Widodo dan $\mathrm{KH}$ Maruf Amin pada pemilihan presiden lalu yang terdaftar di KPU berdurasi 1.30 menit. Jumlah iklan politik terdiri dari tiga iklan yang menyatu dalam satu video. Video iklan pertama tema yang diangkat yaitu tentang tiga kartu unggulan: Kartu Prakerja, Kartu Sembako, dan Kartu Indonesia Pintar Kuliah.

Penanda verbal (tuturan lisan) yang muncul yaitu seorang narator laki-laki menyampaikan narasi tentang harapan 5 tahun ke depan yaitu ingin negara Indonesia yang tercinta ini maju. Tuturan tersebut berbunyi "Dalam 5 tahun ke depan tentunya kita ingin negara tercinta ini lebih maju lagi".

Penanda verbal tersebut disertai dengan penanda nonverbal atau visual 
berupa aktivitas lalu lintas di salah satu jalan di kota Jakarta yaitu Bundaran HI pada malam hari. Lampu-lampu yang menyala berasal dari kendaraan yang sedang melintas, gedung-gedung pencakar langit, dan fasilitas penerangan jalan. Saat narator menceritakan harapan agar negara ini lebih maju lagi. Penanda nonverbal yang muncul yaitu kereta api (LRT) yang tengah maju melewati salah satu stasiun.

Selanjutnya, penanda verbal yang muncul yaitu suara calon presiden nomor urut 01 , Joko Widodo yang menyatakan "Kartu prakerja, lulusan sekolah langsung kerja. Jurus manjur anti nganggur".

Narasi yang disampaikan Joko Widodo pada saat mengatakan "kartu prakerja, lulusan sekolah langsung kerja" diikuti oleh penanda nonverbal yaitu seseorang laki-laki yang tengah memegang dan melihat kartu berisi biodata seseorang. Kemudian saat narasi "jurus manjur, anti nganggur" disebutkan, penanda visual yang muncul yaitu tiga orang laki-laki dan seorang perempuan. Seorang laki-laki yang sedang mengoperasikan laptop berbicara dengan laki-laki lainnya yang memegang kertas. Selain itu, seorang laki-laki lain berbicara dengan seorang perempuan yang sedang memegang pakaian jas. Penanda nonverbal lainnya yaitu sejumlah pakaian yang tergantung di tempat gantungan dan sebuah laptop.

Pada sistem atau tingkat pertama (denotasi), penanda atau ekspresi (E) yang muncul dalam video yaitu penanda Kartu Prakerja. Relasi penanda dengan petanda (C) tingkat pertama dari Kartu Prakerja adalah kartu berisi identitas seseorang yang belum memiliki pekerjaan untuk kalangan fresh graduate, pengangguran dan korban pemutusan hubungan kerja (PHK). Kartu tersebut dapat digunakan mereka untuk memperoleh pelatihan keterampilan dan keahlian selama tiga bulan, dan diharapkan sesudah itu bisa terserap di dunia kerja. Mereka pun mendapat insentif maksimal tiga bulan sebesar Rp. 300-500 ribu perbulan. Target Kartu Prakerja adalah sebanyak 2 juta masyarakat pada 2020.

Pada sistem atau tingkat kedua (konotasi), ekspresi (E) atau penanda yaitu Kartu Prakerja. Relasi penanda terhadap petanda (C) tingkat kedua yaitu Joko Widodo ingin mengatakan atau menyampaikan pesan bahwa Kartu Prakerja menjadi jawaban bagi masyarakat yang ingin mendapatkan pekerjaan, sebab Joko Widodo menjanjikan bahwa bagi lulusan sekolah akan langsung mudah mendapatkan kerja. Kartu Prakerja diklaim menjadi solusi yang ampuh untuk mengatasi permasalahan pengangguran dan masyarakat tidak perlu khawatir. Hal itu diperkuat dengan penanda nonverbal sekelompok pemuda yang tengah bekerja hasil dari mengikuti program Kartu Prakerja. Narasi Kartu Prakerja yang dikatakan Joko Widodo berkaitan dengan upaya politik untuk menggaet kalangan muda untuk 


\section{CAPTURE}

memilih dirinya.

Narasi dilanjutkan dengan suara Joko Widodo yang berbicara tentang sembako murah, dengan penanda nonverbal yaitu seorang perempuan berkerudung sedang memegang kartu dengan jarinya dan jari satu orang lainnya berisi tulisan kartu sembako murah dan gambar burung Garuda serta gambar pulau di Indonesia. Penanda nonverbal lainnya di belakang kartu tersebut yaitu aktivitas seorang perempuan yang sedang membereskan bahan pokok sayuran. Narasinya berbunyi "Sembako murah, bahan pokok terjangkau, ibu-ibu tidak perlu galau"

Pada sistem atau tingkat pertama (denotasi), penanda atau ekspresi (E) yang muncul dalam video yaitu penanda Kartu Sembako Murah. Relasi penanda dengan petanda (C) tingkat pertama dari Kartu Sembako Murah yaitu kartu yang diperuntukan untuk masyarakat kurang mampu dengan diberikan dana sebesar Rp. 1,8 juta per tahun untuk satu kepala keluarga pada 2020. Kartu Sembako Murah merupakan bentuk baru dari program Bantuan Pangan Non Tunai (BPNT). Dana tersebut diberikan kepada 15,6 juta warga penerima manfaat.

Pada sistem atau tingkat kedua (konotasi), ekspresi (E) atau penanda yaitu Kartu Sembako Murah. Relasi penanda terhadap petanda $(C)$ tingkat kedua yaitu pesan yang ingin disampaikan kepada masyarakat yaitu dengan kartu tersebut, warga tidak perlu khawatir dengan hargaharga sembako, sebab sembako dijamin akan lebih murah dan terjangkau, sehingga masyarakat tidak perlu galau. Kartu tersebut menjadi solusi bagi permasalahan hargaharga sembako yang mahal.

Narasi selanjutnya, penanda verbal suara Jokowi yang berbicara tentang rencana peluncuran Kartu Indonesia Pintar (Kuliah). Joko Widdodo berkata "Kita akan luncurkan KIP Kuliah, menjadikan Indonesia negeri berjuta sarjana, negeri para juara. Optimis Indonesia maju,"

Penanda verbal yang ada disertai penanda nonverbal yaitu seorang perempuan berkacamata yang memakai atribut toga sarjana sedang memegang Kartu Indonesia Pintar. Kemudian, saat Jokowi mengatakan "negeri para sarjana dan negeri para juara", petanda nonverbal yang muncul yaitu dua orang laki-laki yang memakai toga sarjana menghadap ke jendela di sebuah ruangan sedang memegang kertas yang digulung memakai pita sambil mengangkat kedua tangan yang dikepalkan.

Pada sistem atau tingkat pertama (denotasi), penanda atau ekspresi $(E)$ yang muncul dalam video yaitu penanda Kartu Indonesia Pintar Kuliah. Relasi penanda dengan petanda $(\mathrm{C})$ tingkat pertama adalah Kartu Indonesia Pintar Kuliah merupakan kartu yang diperuntukan untuk masyarakat kurang mampu yang ingin melanjutkan 
kuliah. Fasilitas yang diberikan yaitu dana operasional kuliah dan dana biaya SPP per semester untuk masyarakat Indonesia. Penerima manfaatnya bisa berasal dari pemegang Kartu Indonesia Pintar.

Pada sistem atau tingkat kedua (konotasi), penanda atau ekspresi (E) relasinya terhadap petanda (C) yaitu dengan program tersebut, maka Indonesia akan lebih banyak memiliki sarjana dan melahirkan para juara, serta akan membuat Indonesia lebih maju. Narasi yang dibangun adalah Kartu Indonesia Pintar Kuliah akan membuat Indonesia lebih maju termasuk masyarakatnya. Hal itu diperkuat dengan penanda nonverbal yaitu beberapa orang pemuda yang berhasil menjadi sarjana setelah menggunakan kartu tersebut.

Penanda verbal suara Joko Widodo yang mengatakan "optimis, Indonesia maju" dilengkapi dengan penanda nonverbal yaitu gambar foto Joko Widodo yang sedang swafoto dengan orang-orang di sekelilingnya. Kemudian, sebagiannya lagi memotret Jokowi dari jauh. Gambar foto Jokowi berwarna, sedangkan orang-orang di sekelilingnya berwarna hitam putih.

Pada sistem pertama (denotasi), penanda $(E)$ yang muncul adalah Indonesia maju. Relasi terhadap petanda (C) yaitu Indonesia maju adalah sebuah negara dengan jumlah penduduk lebih dari 260 juta dengan pencapaian pembangunan infrastruktur dan sumber daya manusia serta memiliki peringkat bagus.
Pada sistem kedua (konotasi), penanda (E) Indonesia maju relasinya terhadap (C) adalah representasi dari Indonesia maju adalah sosok Joko Widodo. Pesan itu diperkuat oleh penanda nonverbal berupa visualisasi Jokowi sebagai sosok yang bersinar di antara orang-orang lainnya yang hanya berwarna hitam putih.

Narasi kemudian yang muncul adalah penanda verbal yang mengatakan "Kita pilih Jokowi lagi". Penanda nonverbal yang muncul yaitu gambar foto pasangan Jokowi dan $\mathrm{KH}$ Maruf yang memakai pakaian koko putih dan kopiah sambil tersenyum dengan latar belakang gambar foto putih. Selain itu, penanda nonverbal yaitu tulisan Jokowi Amin Indonesia Maju. Tulisan Jokowi warna merah, tulisan Amin warna hitam, dan Indonesia Maju abu-abu, sedangkan tulisan 01 berwarna putih dengan latar belakang berbagai macam warna seperti merah, kuning, biru, oranye, dan hijau.

Pada sistem pertama (denotasi) penanda $(E)$ yang muncul adalah kalimat "Kita pilih Jokowi lagi". Relasi terhadap (petanda) yaitu Jokowi adalah seorang lelaki berusia 58 tahun yang memiliki seorang istri, Iriana, dan tiga orang anak. Sosok yang pernah menjabat sebagai Wali Kota Solo dan Gubernur DKI Jakarta ini memiliki perawakan kurus.

Pada sistem kedua (konotasi), penanda (E) Jokowi memiliki relasi terhadap petanda (C) yaitu sosok yang merakyat, 
sederhana, dan dekat dengan rakyat. Pesan yang ingin disampaikan adalah pilihlah Jokowi, sosok pemimpin sederhana yang bisa membawa Indonesia lebih maju.

Citra dalam video pertama yang direpresentasikan kepada masyarakat adalah sosok Joko Widodo sebagai pemimpin sederhana dan merakyat yang bisa membawa Indonesia lebih maju. Tiga programnya tentang kartu akan menyelesaikan persoalan dasar yaitu pendidikan, pekerjaan, dan kebutuhan pokok masyarakat.

\subsection{Iklan Jokowi Blusukan}

Iklan kedua mengangkat tema Jokowi dan KH Maruf Amin yang melakukan kegiatan blusukan. Iklan dimulai dengan petanda verbal yaitu seorang narator perempuan berbicara tentang saat akan memilih seorang presiden.

Narasi berbunyi "Saat kita akan memilih seorang presiden" disertai dengan penanda nonverbal yaitu gambar seorang seorang laki-laki dewasa sedang menggendong anak kecil di pundaknya dengan latar pepohonan. Kemudian, dilanjutkan dengan seorang laki-laki dewasa lainnya yang sedang menancapkan kayu ke tanah menggunakan palu sebagai penyangga tenda. Di sebelahnya tampak seorang anak kecil ikut membantu dengan memegang kayu tersebut. Laki-laki dewasa tersebut memasang selotip hitam di bagian atap rumah-rumahan, sedangkan anak kecil sedang memperhatikannya. Narator melanjutkan berbicara memilih presiden sama dengan memilih seorang figur bapak. "Sama kaya milih seorang figur bapak"

Petanda nonverbal yang menyertai suara tersebut yaitu gambar seorang lakilaki dewasa memakai kopiah sedang bersujud dengan alas sajadah. Visualisasi berikutnya seorang laki-laki dewasa lainnya sedang menuntun seorang anak kecil memakai pelindung kepala sambil mengendarai sepeda. Akhirnya digambarkan adegan seorang laki-laki dewasa sedang melihat anak perempuan memasukkan uang ke dalam celengan berbentuk ayam. Narator melanjutkan berbicara "Bapak yang peduli dan hadir di saat kita butuh"

Penanda nonverbal yang muncul pada narasi tersebut yaitu seorang laki-laki dewasa dan perempuan dewasa sedang memayungi seorang anak kecil karena hujan dan mengantarkannya ke dalam mobil. Penanda nonverbal lainnya yaitu seorang anak kecil yang sedang menggunakan alat pengukur suhu tubuh di mulut, kemudian seorang laki-laki dewasa memberikan makan bubur kepada anak tersebut.

Pada sistem pertama (denotasi), penanda (E) yang muncul adalah presiden dan bapak. Relasi terhadap petanda (C) yaitu presiden adalah pemimpin negara yang mengeluarkan kebijakan untuk kepentingan dan kesejahteraan masyarakat. Bapak adalah sosok pemimpin 
keluarga

Pada sistem kedua (konotasi), penanda $(\mathrm{E})$ yaitu presiden dan bapak relasi terhadap petanda (C) adalah sosok presiden dan bapak adalah seseorang yang sama-sama harus melindungi dan baik kepada masyarakat maupun keluarganya, serta peduli dan hadir untuk semuanya.

Kemudian, muncul penanda nonverbal berikutnya yaitu gambar Joko Widodo yang sedang jongkok sambil menyuapkan makanan kepada seorang anak kecil Papua, diiringi musik Yo Yo Ayo. Kemudian, Joko Widodo berkendara motor dengan istrinya, membagikan buku kepada anak-anak Papua, bersalaman dengan ibuibu Papua di pasar, dilanjutkan dengan menjadi imam salat. Narator menyampaikan kalimat "Itu bapak yang baik", diikuti petanda nonverbal yaitu $\mathrm{KH}$ Maruf Amin sedang menengok seorang warga yang sakit. Lalu, seorang anak kecil yang membawa bendera merah putih dipangku seorang laki-laki dewasa mengejar Joko Widodo ingin bertemu langsung dan seorang nenek yang memeluk Joko Widodo sambil menangis.

Pada sistem pertama (denotasi) penanda $(E)$ yang muncul adalah Jokowi. Relasi terhadap (C) yaitu Jokowi adalah seorang lelaki yang baik dan dekat dengan masyarakat. Sistem kedua (konotasi), penanda (E) yaitu Jokowi memiliki relasi terhadap petanda $(\mathrm{C})$ yaitu sosok yang baik, merakyat, dan membantu siapapun serta hadir untuk mereka yang serba kekurangan. Penanda nonverbal seorang anak dan orang tua yang mengejar dan memeluk Jokowi, pesan yang ingin disampaikan adalah kehadiran Jokowi dicintai oleh masyarakat.

Selanjutnya, Joko Widodo melalui penanda verbal mengajak orang-orang untuk membangun negera meski dalam kondisi sulit. Joko Widodo mengatakan "Sesulit apapun tantangan itu, sesulit apapun hambatan itu. Kita harus bersama sama membangun negara ini". Sistem pertama (denotasi) yaitu penanda $(E)$ membangun negara memiliki relasi terhadap petanda $(\mathrm{C})$ yaitu memajukan dan meningkatkan kemajuan masyarakat di sebuah negara. Sistem kedua (konotasi) yaitu penanda $(E)$ yaitu membangun negara memiliki relasi terhadap petanda $(\mathrm{C})$ yaitu membangun negara Indonesia bisa terwujud jika pemimpin Indonesia adalah dirinya karena optimis Indonesia akan lebih maju dan dicintai oleh masyarakat.

Petanda nonverbal yang mengikuti narasi itu adalah seorang anak kecil yang membawa bendera merah putih plastik dipangku seorang laki-laki dewasa mengejar Jokowi ingin bertemu langsung dan seorang nenek yang memeluk Jokowi sambil menangis. Kemudian, kaki seorang laki-laki berjalan di atas jalan yang rusak kemudian Jokowi memakai atribut pakaian $\mathrm{TNI}$ bersalaman dengan orang-orang dan dijaga ketat oleh pengaman. 


\section{CAPTURE}

Petanda nonverbal berikutnya yaitu Jokowi dengan atribut pakaian putih mengajak untuk membangun negara dengan latar belakang pertama pepohonan dan dilanjutkan dengan latar belakang gedung dan narasi suara Jokowi "Optimis Indonesia maju".

Iklan kedua ini tampak citra yang direpresentasikan adalah sosok Joko Widodo adalah seorang bapak yang dekat dengan masyarakat, memahami apa yang diinginkan masyarakat, dan dicintai oleh masyarakat. la merepresentaskan diri sebagai seorang bapak yang baik dengan selalu hadir di tengah masyarakat.

\subsection{Iklan Jokowi tentang Kampanye}

Iklan ketiga, tema yang diangkat mengenai Jokowi dan $\mathrm{KH}$ Maruf Amin sedang berkampanye mengajak masyarakat memilih dirinya. Penanda verbal yang muncul pada iklan tersebut adalah suara Jokowi yang mengungkapkan "Saudara-saudaraku sebangsa dan setanah air, kita adalah bangsa yang optimis, bangsa yang pantang menyerah. Perubahan demi perubahan akan sia-sia, jika kita hanya saling menilai dan saling menghujat antar sesama. Atas izin Allah SWT, saya Jokowi dan Maruf Amin siap memimpin dan menghantarkan cita-cita masa depan bangsa menjadikan Indonesia maju"

Pada sistem pertama (denotasi), penanda (E) yang muncul adalah bangsa yang optimis dan pantang menyerah. Relasi terhadap petanda (C) melahirkan makna atau konsep bangsa Indonesia adalah bangsa yang selalu melihat sesuatu ke depan dan gigih. Pada sistem kedua (konotasi), penanda (E) yaitu pantang menyerah dan optimis relasi terhadap petanda (C) yaitu Joko Widodo adalah bagian dari masyarakat Indonesia yang memiliki sifat pantang menyerah dan optimis. Penanda nonverbal yang melengkapinya menunjukkan pesan bahwa Joko Widodo sangat diharapkan oleh masyarakat dari berbagai latar belakang.

Penanda nonverbal yang muncul bersamaan dengan petanda verbal tersebut yaitu saat Jokowi mengatakan "Saudarasaudaraku sebangsa dan setanah air", petanda nonverbal yang muncul adalah seorang laki-laki dewasa yang sedang mendengarkan radio di barber shop, seorang laki-laki memakai topi sedang merapihkan jaring, kemudian berkumpul bersama seorang perempuan dewasa dan dua orang anak kecil mendengarkan radio.

Saat narator Jokowi mengatakan "Kita adalah bangsa yang optimis dan bangsa tanpa menyerah", penanda nonverbal yang muncul seorang laki-laki dewasa memakai helm di area pembangunan, dilanjutkan dua orang lakilaki dewasa memakai pakaian koko dan kopiah dengan latar masjid sedang menonton melalui telepon genggam, dan beberapa orang laki-laki dan perempuan dewasa sedang menonton televisi. 
Saat kalimat "perubahan demi perubahan" disampaikan, penanda nonverbalnya yaitu beberapa gedung bertingkat dan kereta cepat. Lalu, dilanjutkan kembali pada penanda nonverbal yaitu seorang lelaki dewasa sedang mencukur dan seorang lelaki dewasa yang mendengarkan radio di sawah; beberapa anak sekolah mendengarkan suara narator dari telepon genggam; beberapa anak muda yang berkumpul di sebuah ruangan sambil berdiskusi dan melihat tontonan di laptop; dan beberapa orang dewasa tengah melihat televisi di pasar.

Penanda nonverbal berikutnya yang muncul adalah video pasangan Jokowi dan $\mathrm{KH}$ Maruf Amin di dalam laptop yang sedang berbicara dan bendera Indonesia di sampingnya. Narasi yang disampaikan yaitu "Siap memimpin dan menghantarkan citacita masa depan bangsa menjadi Indonesia maju".

Citra yang direpresentasikan iklan ketiga yaitu Joko Widodo dan $\mathrm{KH}$ Maruf Amin merupakan pemimpin yang pantang menyerah dan optimis dalam membangun bangsa Indonesia.

\section{SIMPULAN}

Hasil penelitian menunjukkan: 1) video iklan pertama, citra yang direpresentasikan adalah sosok Joko Widodo merupakan pemimpin sederhana dan merakyat yang bisa membawa Indonesia lebih maju; 2) iklan kedua. citra yang direpresentasikan adalah sosok Joko Widodo adalah seorang bapak yang baik dan selalu hadir di kalangan masyarakat; dan 3) iklan terakhir, citra yang direpresentasikan oleh Joko Widodo dan $\mathrm{KH}$ Maruf Amin adalah pemimpin yang pantang menyerah dan optimis dalam membangun bangsa Indonesia.

Secara keseluruhan, iklan kampanye Jokowi-Amin memperlihatkan Jokowi merepresentasikan atau mencitrakan diri sebagai pemimpin sederhana, merakyat, dan dekat masyarakat kecil, serta bisa membawa Indonesia sejahtera melalui program Kartu Prakerja, Kartu Indonesia Pintar Kuliah dan Kartu Sembako Murah.

\section{DAFTAR ACUAN}

Barker, C. (2008). Cultural Studies, Teori dan Praktik. Kreasi Wacana.

Budi, S. (2013). Hasil Survei Nasional tentang Iklan Politik dan Perilaku Pemilih Menjelang Pemilu 2019. PUSKAPOL FISIP UI. https://www.puskapol.ui.ac.id/press -release/hasil-survei-nasionaltentang-iklan-politik-dan-perilakupemilih-menjelang-pemilu2009.html

Danesi, M. (2011). Pesan, Tanda dan Makna, Buku Teks Dasar Mengenal Semiotika dan Teori Komunikasi. Jalasutra.

Dhani, A. (2017). Bagaimana Jokowi Menjual Citra. Tirto.ld. https://tirto.id/bagaimana-jokowimenjual-citra-clCc)

Fauzi, A. (2018). Discourse Analysis of 


\section{CAPTURE}

Pond's Men's Advertising Lelakimasakini Version of Rio Dewanto. CAPTURE: Jurnal Seni Media Rekam, 9(2), 15-26. https://doi.org/10.33153/capture.v9i 2.2087

Hoed, B. H. (2011). Semiotika dan Dinamika Sosial Budaya. Komunitas Bambu.

Kemp, S. (2019). Global Digital Report 2019 (We Are Social). https://wearesocial.com/globaldigital-report-2019

Krismantari, I. (2018). Motor Besar, Sneaker dan Jaket Jins: Jurus Pencitraan Jokowi untuk Memenangkan Hati Pemilih Pemula 2019. The Conversation.Com. http://theconversation.com/motorbesar-sneaker-dan-jaket-jins-juruspencitraan-jokowi-untukmemenangkan-hati-pemilihpemula-di-2019-94985)

Liputan6com. (2019). Digugat karena Foto Terlalu Cantik Caleg DPD ini Sampaikan Pembelaan di Sidang MK. Liputan6com. https://www.liputan6.com/pileg/rea d/4016139/digugat-karena-fototerlalu-cantik-caleg-dpd-inisampaikan-pembelaan-di-sidang$\mathrm{mk}$

Narendra, A. N., Habsari, S. K., \& Ardianto, D. T. (2019). Form of Standardization and Stereotyping Practices through Message of Video Ads Buavita. CAPTURE: Jurnal Seni Media Rekam, 10(2), 107-125.

https://doi.org/10.33153/capture.v1 $0 \mathrm{i} 2.2243$

Piliang, Y. A. (2019). Semiotika dan Hipersemiotika, Kode, Gaya dan Matinya Makna (IV). Cantrik
Pustaka.

Prasetyo, B. (2019). Usai Pertemuan Jokowi dan Prabowo Swafoto bersama Wartawan. Antaranews. https://www.antaranews.com/berita /1108096/usai-pertemuan-jokowidan-prabowo-swafoto-bersamawartawan

Prasetyo, Y. A. (2018). Praktik Abal-Abal versus Perlindungan Pers. Jurnal Dewan Pers, 18(November), 1223.

Rully. (2018). Efektivitas Iklan Negatif di Media Sosial dalam Politik di Indonesia. Jurnal Lontar, 6, 69-79.

Rusmulyadi, \& Hafiar, H. (2018). Dekontruksi Citra Politik Jokowi dalam Media Sosial. Jurnal Profesi Humas, 3, 120-140.

Setianto, W. A., Pratikno, Prajarto, N., \& Ambardy, K. (2016). Wacana dan Representasi Ideologi Iklan Politik Indonesia di Era Reformasi. UGM.

Storey, J. (2008). Cultural Studies dan Kajian Budaya Pop: Pengantar Komperhensif Teori dan Metode. Jalasutra.

Subinarto, J. (2019). Efektivitas Iklan Politik. https://www.google.com/amp/s/kolo m.tempo.co/amp/1189882/efektivit as-iklan-politik

Tinarbuko, S. (2009). Semiotika Komunikasi Visual. Jalasutra.

Wikipedia. (2019). Media Sosial. In Wikipedia. https://id.wikipedia.org/wiki/Media_ sosial 